\title{
Brazilian contribution for a better knowledge on the biology of Toxoplasma gondii
}

\author{
Wanderley de Souza1 ${ }^{1}{ }^{\text {, }}$, Renato A DaMatta ${ }^{2}$, Márcia Attias ${ }^{3}$ \\ ${ }^{1}$ Instituto Nacional de Metrologia, Normalização e Qualidade Industrial, Rio de Janeiro, RJ, Brasil ²Laboratório de Biologia Celular e Tecid- \\ ual, Centro de Biociências e Biotecnologia, Universidade Estadual do Norte Fluminense, Campos dos Goytacazes, RJ, Brasil ${ }^{3}$ Laboratório \\ de Ultraestrutura Celular Hertha Meyer, Instituto de Biofísica Carlos Chagas Filho, Universidade Federal do Rio de Janeiro, CCS-Bloco G, \\ Ilha do Fundão, 21941-900 Rio de Janeiro, RJ, Brasil
}

Historically, scientists in Brazil has significantly contributed to the biology, cultivation and structural organization of the pathogenic protozoan Toxoplasma gondii and its interaction with host cells, starting with the description of the protozoan by Splendore in 1908. The intracellular and extracellular corpuscoli observed in rabbits, corresponded to what we now as tachyzoites. Later on, a pioneering method to grow T. gondii in tissue cultures was developed by Guimarães and Meyer, 1942. They also observed for the first time T. gondii by transmission electron microscopy and made the initial description of the cytoskeleton of T. gondii by observing negatively stained cells. In the 1980's, the relation of the cytoskeleton with the sub-pellicular microtubules was reveled by freeze-fracture. More recently, several Brazilian groups have analyzed in detail basic aspects of the early interaction of the protozoan with the host cell, such as the role of protein phosphorylation, transfer of host cell surface components to the protozoan and genesis and organization of the parasitophorous vacuole. Tachyzoites strategically inhibit nitric oxide production during active invasion of activated macrophages. In vitro studies on the sexual cycle of $\mathrm{T}$. gondii using primary cultures of cat enterocytes and the egress from host cells are being carried out. Perspectives are that the contribution of Brazilian science to the knowledge on T. gondii biology will continue to flourish in years to come.

Key words: Toxoplasma gondii - Brazilian contribution - ultrastructure - host cell interaction

The end of the XIX and the beginning of the XX century (30 years period) were a landmark for the biomedical sciences when several new important parasitic protist species, many identified as causal agents of important human diseases, were discovered. As a matter of fact, in 1880, Laveran described the genus Plasmodium and later, in 1903, the same Laveran, described Leishmania donovani. In the sequence, in 1907, Forde described Trypanosoma gambiense and, in 1908, Toxoplasma gondii was described. In 1909, Chagas described Trypanosoma cruzi and Pneumocystis carinii. In 1911, Viana described Leishmania braziliensis. For the Brazilian science, the first 10 years of the XX century were remarkable since Brazilian scientists were involved in the description of $T$. gondii, $P$. carinii, T. cruzi and L. braziliensis.

As far as T. gondii is concerned, in 1909 Splendore, at that time working as director of the Bacteriological Laboratory of Hospital Português, in São Paulo, Brazil, had the opportunity to examine rabbits presenting an acute infectious process which lead to death. Pathological examination showed the presence of speciali corpuscoli, well stained with Giemsa, distributed in several tissues. The size of the corpuscoli was 5-8 $\mu \mathrm{m}$ long and 2.5-4 $\mu \mathrm{m}$

Financial support: CNPq, FINEP, FAPERJ

+ Corresponding author: wsouza@biof.ufrj.br

Received 10 October 2008

Accepted 29 October 2008 wide. Splendore sent the material to the great protozoologist Prowazek, at that time working in Rio de Janeiro. Both agreed that the corpuscoli belonged to a new group of protozoa. The communication was published in the Revista da Sociedade Scientifica de São Paulo, n. 10-12, 1908. In the same year, Nicolle and Manceau found the same protozoan in the rodent Ctenodactylus gondii captured in Tunis. In 1909, both Splendore (1909) and Nicole and Manceau (1909) published separately two other papers supporting the initial description. The new genus and the new species were designated by Nicolle and Manceau as T. gondii and Toxoplasma cuniculi. In 1914, Arantes made an important survey on the available data on T. gondii. His work was presented as a Doctoral Thesis to the Rio de Janeiro School of Medicine.

Another important Brazilian contribution was the initial description, in 1927, by Magarinos Torres, a brilliant pathologist working at the Instituto Oswaldo Cruz, of congenital toxoplasmosis.

Cultivation - A second major historical contribution from the Brazilian science was published in 1942, by Guimarães and Meyer, who set up a methodology for the cultivation of $T$. gondii in tissue culture. At that time, FN Guimarães and Hertha Meyer (1942), who initially worked with Fisher in Berlin and Levi in Turin, set up a tissue culture laboratory at the Instituto de Biofísica at the Federal University of Rio de Janeiro and made the first reproducible studies on the cultivation of $T$. gondii (Fig. 1A, B, C), T. cruzi and Plasmodium gallinaceum, reporting her observations in papers published in the 40's. More recently, Barbosa et al. (2005), working at 
the Instituto Oswaldo Cruz, in Rio de Janeiro, made the first attempts, using primary cultures of intestinal cells from cat embryos, to reproduce in vitro the sexual cycle of the protozoan.

The fine structure - Meyer and Mendonça (1955, 1957) were among the first to use transmission electron microscope to analyze the fine structure of $T$. gondii, $T$. cruzi and P. gallinaceum. Indeed, the work published in 1957 (Meyer \& Mendonça 1957) was the first to describe long, homogeneous dark stained inclusions, which clearly correspond to the rhoptries and dense granules (Fig. 2), now recognized as characteristic of the Apicomplexa phylum. One of us (WS) had the opportunity to join the group in 1969 and initiated a series of studies. The use of the negative staining technique allowed the visualization of the whole cytoskeleton composed of sub-pellic-

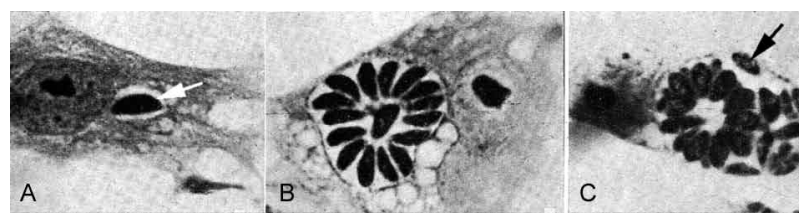

Fig. 1: light microscopy of Toxoplasma gondii tachyzoites developing inside chicken embryo culture cells. A: early infection with a single tachyzoite (arrow) inside a parasitophorous vacuole; B: rosette of tachyzoites around a residual body; C: late stage of the intracellular cycle with tachyzoites already leaving the parasitophorous vacuole (arrow). Giemsa stained. Original magnification 1,100X (Guimarães \& Meyer 1942).

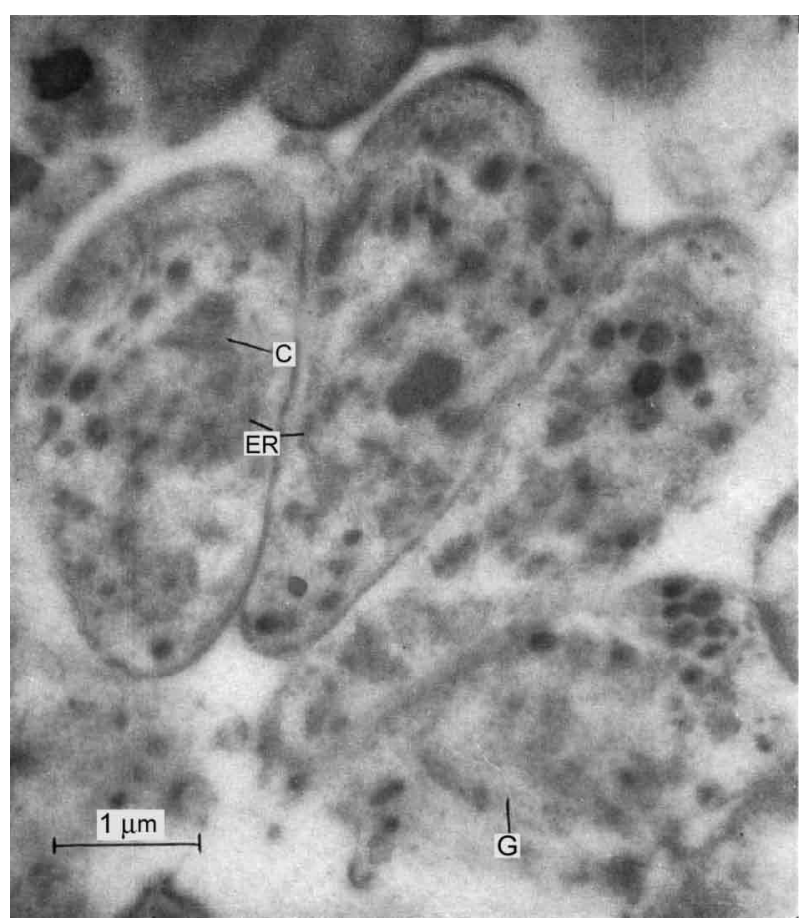

Fig. 2: first electron micrograph of a thin section of a rosette of tachyzoites. A conoid (C), the endoplasmic reticulum (ER) and dense granules $(\mathrm{G})$ can also be recognized. Bar $=1 \mu \mathrm{m}$ (Meyer $\&$ Andrade Mendonça 1957). ular microtubules (Fig. 3) and the sub-structure of the conoid (Fig. 4). These observations lead to the suggestion that this structure is made of rings and microtubules and change its shape and length (Fig. 4a), resulting in the proposition of a three-dimensional model for its structure (Fig. 5) (De Souza 1972, 1974a). After the initial morphological descriptions by transmission electron microscopy in the 1970's and 1980's several papers produced by Brazilian groups were focused on the application of new techniques to the study of $T$. gondii tachyzoites. Of particular interest, even today, is the report of the selective staining of secretory organelles (rhoptries, micronemes and dense granules) as well as the conoid and the subpelicular microtubules by ethanolic phosphotungstic acid, specific for the detection of basic proteins (Fig. 6) (De Souza \& Souto-Padron 1978). This preparation method is particularly valuable to produce semithin sections for reconstruction of these structures by electrontomography. Freeze fracture of tachyzoites (Cintra \& De Souza 1985) also showed intramembranous particles distributed in parallel arrays with the same spacing and periodicity of the subpelicular microtubules (Fig. 7), establishing an ultrastructural relationship between them and the inner membrane complex, as proposed in the models for gliding motility (reviewed in Baum et al. 2006). These observations were reinforced when protein bridges between the inner membrane complex and the subpellicular microtubules were also found in detergent extracted tachyzoites fixed in the presence of tannic acid. Furthermore, freeze fracture of infected cells

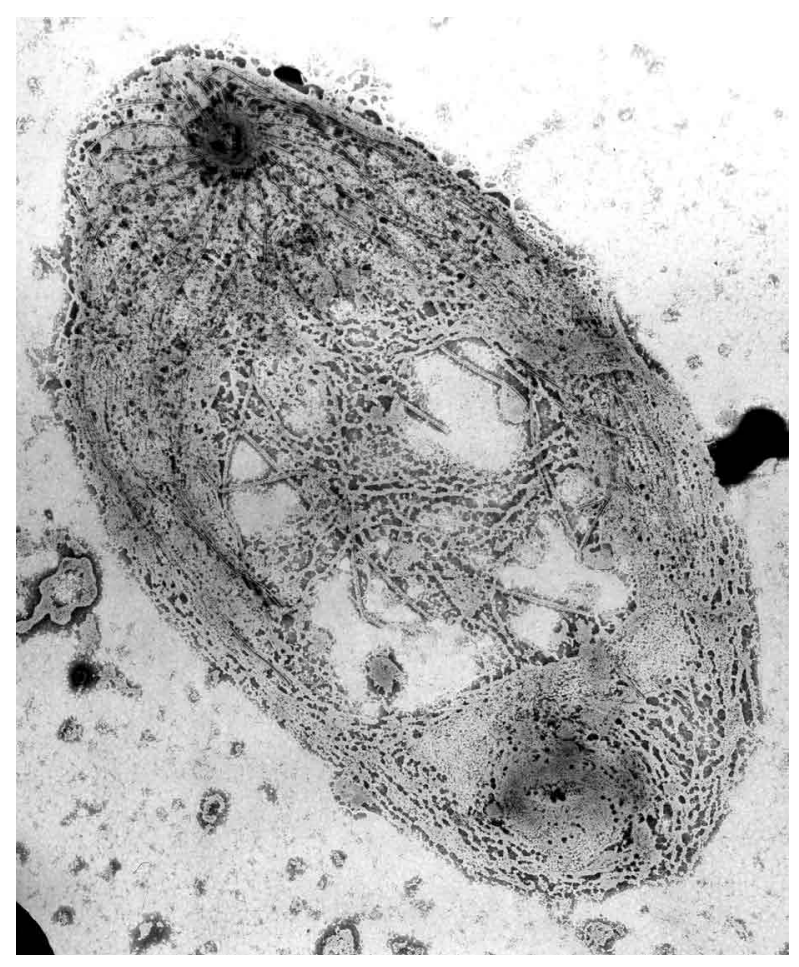

Fig. 3: negative staining of a tachyzoite after membrane extraction. The subpellicular microtubules around the posterior polar ring and the conoid can be individualized. Bar $=1 \mu \mathrm{m}$ (De Souza 1972). 


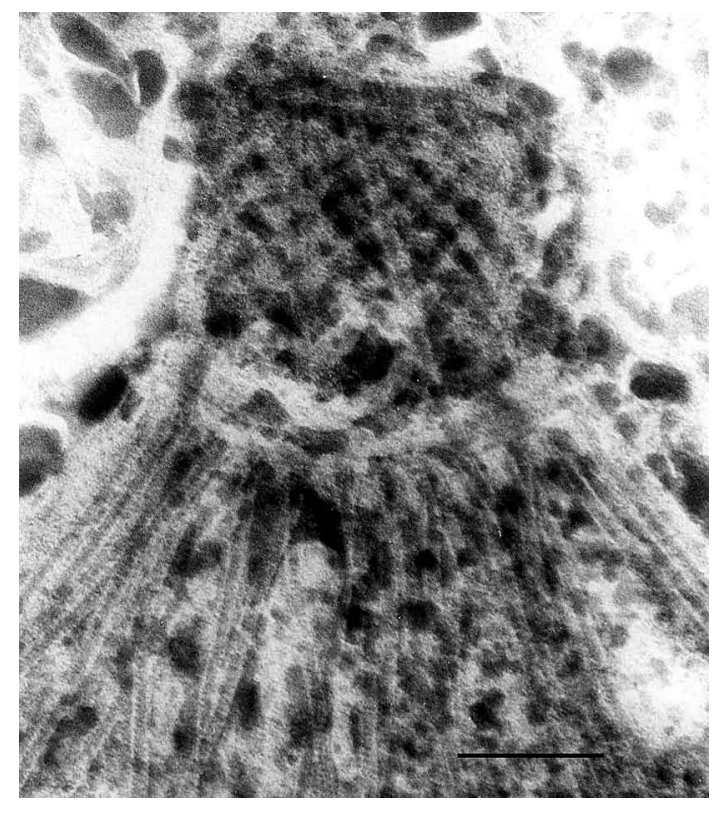

Fig. 4: negative staining of the anterior portion of a tachyzoite showing the fibrilar lattice of the conoid, the anterior and posterior rings, the central pair of microtubules inside the conoid and the subpellicular microtubules around the polar ring. Bar $=200 \mathrm{~nm}$ (De Souza 1974b).

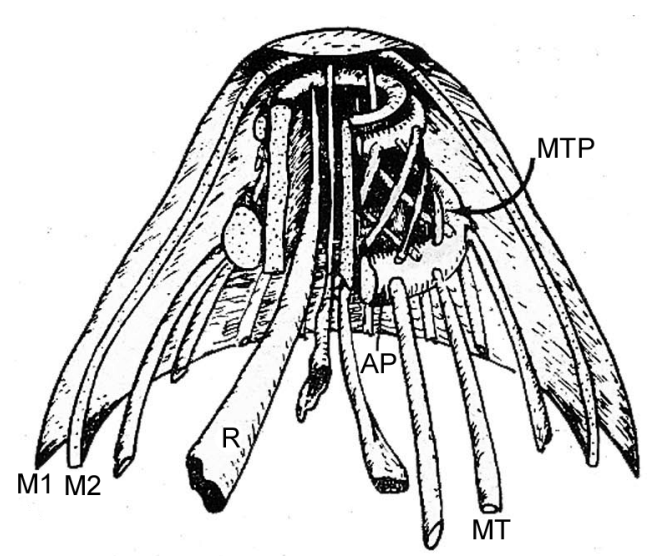

Fig. 5: first scheme of the apical portion of a tachyzoite showing the three membrane layers of the pellicle, rhoptries (R) inside the conoid and the spiral lattice of its fibrils (MTP). The polar ring (AP) and subpellicular microtubules (MT) are also represented (De Souza 1974b). M1: outer membrane; M2: inner membrane complex.

treated with filipin showed the presence of cholesterol, an important component that is obtained from host cells, in the plasma, but not in the inner membrane complex of tachyzoites (Cintra \& De Souza 1985).

More recently, the ultrastructure and cell biology of the tachyzoite was reexamined and the activity of the single mitochondrion (Fig. 8) of intra and extra cellular tachyzoites was show with the use of the fluorescent compound CMXRos and observation by laser scanning confocal microscopy and computer aided 3-D reconstruction from serial sections, two cutting edge approaches at that time (Melo et al. 2000). A multiple technical approach,

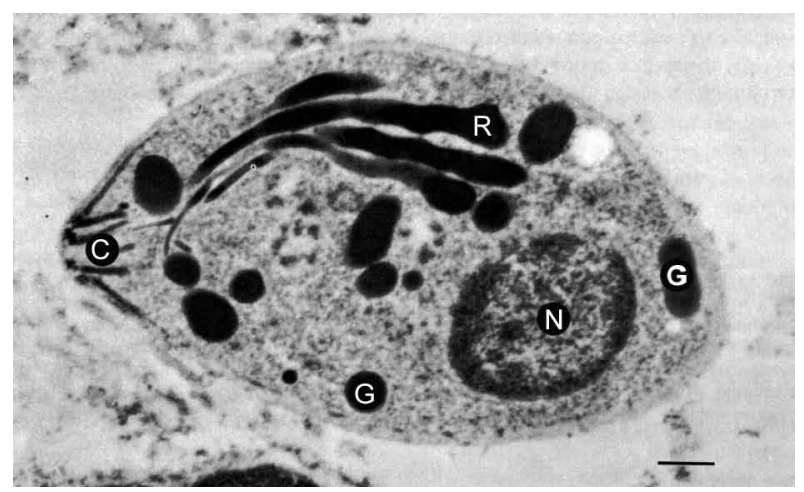

Fig. 6: longitudinal section of a tachyzoite fixed in glutaraldehyde and incubated in the presence of ethanolic phosphotungstic acid before embedding. Basic proteins were shown to be present in the conoid (C), rhoptries (R), dense granules $(\mathrm{G})$ and nucleus $(\mathrm{N})$. Bar $=500 \mathrm{~nm}(\mathrm{De}$ Souza \& Souto-Padron 1978).

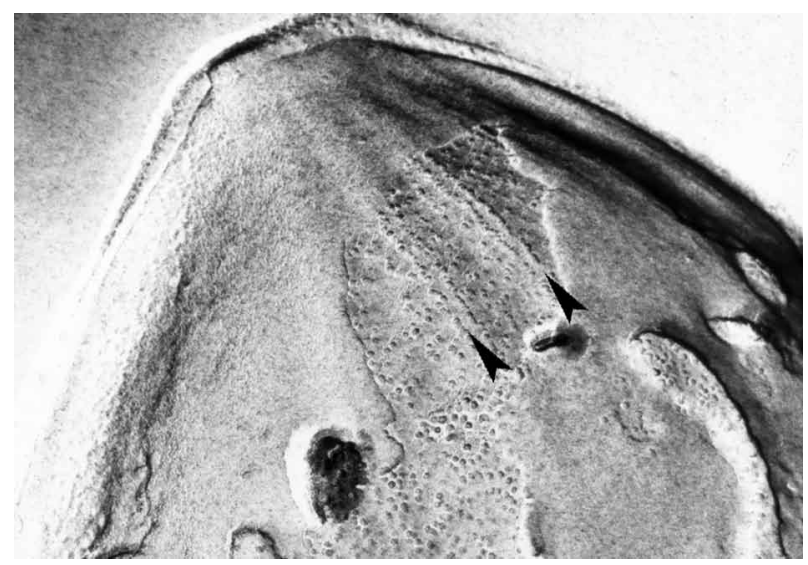

Fig. 7: freeze fracture replica of a tachyzoite showing parallel arrays of intramembranous particles (arrowheads) with the same distribution of the subpellicular microtubules in the inner membrane. Original magnification 67,000X (Cintra \& De Souza 1985).

including light and transmission electron microscopy, freeze fracture, field emission scanning electron microscopy and 3-D reconstruction was also employed by Monteiro et al. (2001) in the analysis of the conoid of tachyzoites in the inserted and extruded states.

Interaction with host cell - This is an area where several Brazilian groups have worked in the last years. Employing a chronological order, and considering primarily an ultrastructural approach, after the works by Silva et al. (1982), Meirelles et al. (1983) and Meirelles and De Souza (1985) on basic aspects of the invasion and survival of $T$. gondii in primary cell lines; the effect of various digestive enzymes and the cytochemical localization of plasma membrane enzyme markers during interiorization of tachyzoites of $T$. gondii by macrophages have been analysed by De Carvalho and De Souza (1989). The role of anionic sites, sugar residues and protein phosphorilation was covered in the works by De Carvalho and De Souza (1990), De Carvalho et 
al. (1991), Stumbo et al. (2002) and Ferreira et al. (2003). One important contribution, whose results have not been completely explored up to now, was made in experiments where the surface of host cells were labeled before tachyzoites invasion. After binding of the parasite to the host cell, the labeled lipids, proteins and glycoconjugates were transferred to the protozoan surface and subsequently found in the parasitophorous vacuole (Pacheco Soares \& De Souza 2000) (Fig. 9). The redistribution of mitochondria and endoplasmic reticulum in host cells infected with $T$. gondii has also been shown by de Melo et al. (1992) and, more recently, by Magno et al. (2005). The host cell cytoskeleton was also shown to take part in the establishment of the parasitophorous vacuole by Andrade et al. (2001). More recently, the intranuclear localization of tachyzoites was also reported by Barbosa et al. (2005). This same group has reported that infection of primary cultures of skeletal muscle cells of mice with bradyzoites is a model for $T$. gondii cystogenesis (Guimarães et al. 2008).

Field emission scanning electron microscopy has brought new insights and amazing views of the process of invasion of neutrophils (Fig. 10) (MacLaren et al. 2004) and the intravacuolar behavior of tachyzoites in non phagocytic cells (Magno et al. 2005) with special relevance on the organization and putative structural role of the intravacuolar network of tubular membranes.

Interaction with macrophages - One of the legacies of Hertha Mayer, as previously mentioned, was cell culture. At that time, chicken embryos were easily obtained and were used, resulting in the hang drop cell culture technique. Another host cell model was chicken macrophages derived form blood monocytes. This cell type

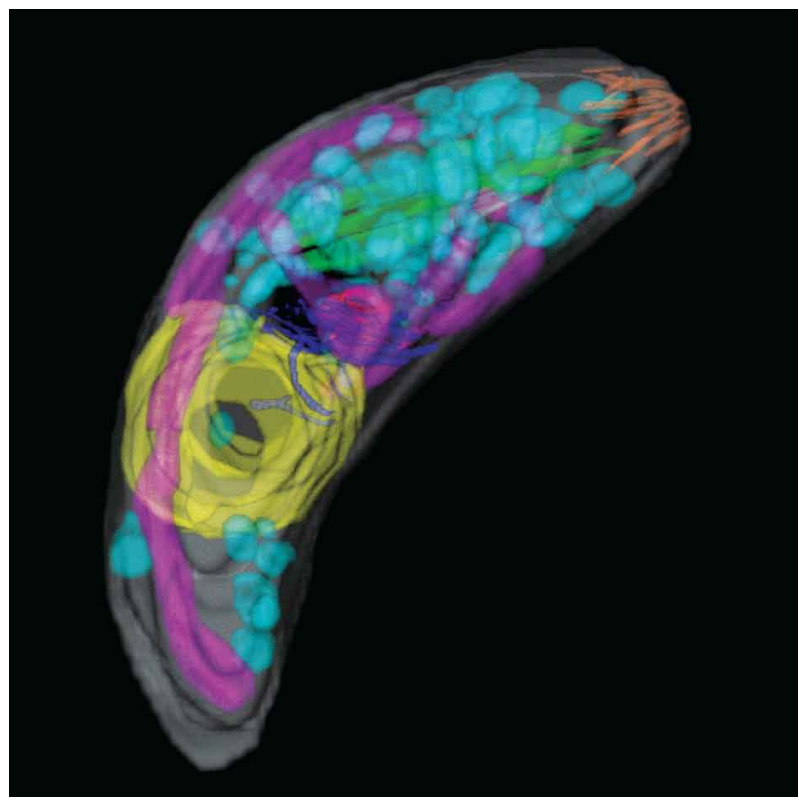

Fig. 8: three dimensional model of a tachyzoite reconstructed from serial sections, showing the single mitochondrion (magenta), the nucleus (yellow), rhoptries (green), Golgi complex (navy blue), apicoplast (red) and dense granules (blue) (Melo et al. 2000). was used later on by one of us (WS) to show that chicken macrophages could destroy trypomastigotes of $T$. cruzi and promastigotes of Leishmania, but not tachyzoites of T. gondii (Meirelles \& De Souza 1985). This experimental model was used also in an attempt to find out if nitric oxide (NO) was involved in this killing. It was shown that NO was not related to the killing of T. cruzi, actually it was the respiratory-burst activity that was responsible for the microbicidal action of these macrophages to $T$. cruzi (DaMatta et al. 2000). As expected, the survival of $T$. gondii in these macrophages was due to its evasion mechanism on the oxygen radicals burst (Murray
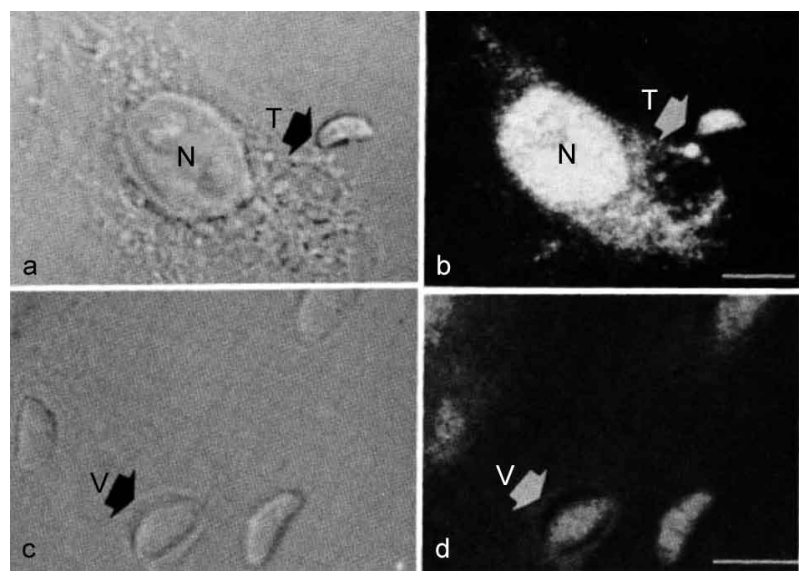

Fig. 9: vero Cells previously labeled with DTAF and then allowed to interact with tachyzoites for 5 (a-b) and $30 \mathrm{~min}(\mathrm{c}-\mathrm{d})$. Labeling is transferred from the host cell plasma membrane to the parasite (T) and internalized during formation of the parasitophorous vacuole (V) (c-d); N: nucleus (Pacheco-Soares \& De Souza 1998).

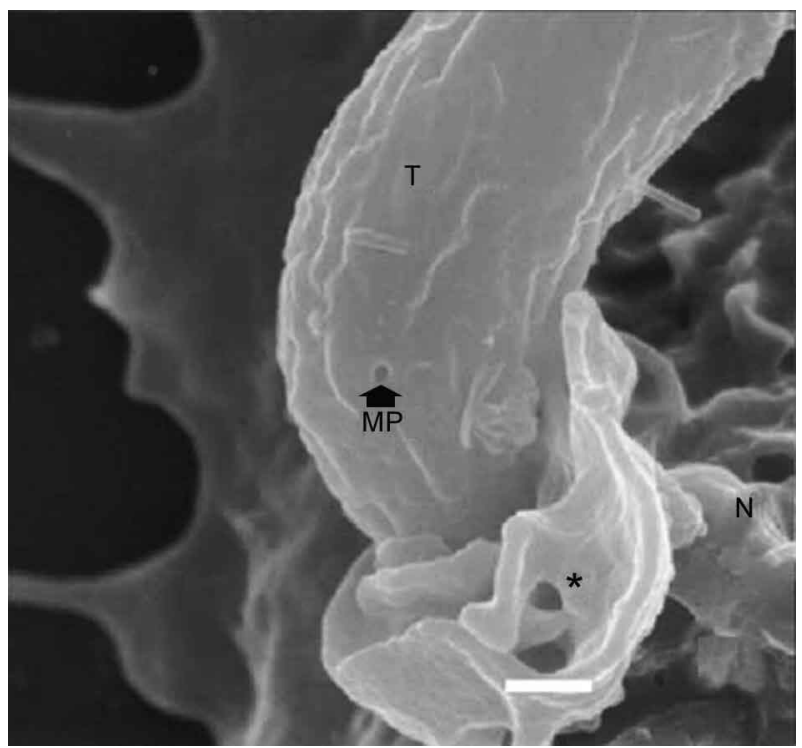

Fig. 10: field emission scanning electron microscopy of a tachyzoite (T) invading a neutrophil $(\mathrm{N})$. A ruffling lamellipodium (star) embraces the parasite. The arrow points to the micropore (MP). Bar $=1 \mu \mathrm{m}$ (MacLaren et al. 2004). 
\& Cohn 1979, DaMatta et al. 2000). As a NO production control, mice macrophages activated with interferongamma and lipopolysaccharide were used and, in an unexpected way, it was reported that infection by $T$. gondii reduced NO production (DaMatta et al. 2000). Following this line of evidences, it was shown that a reduction of NO production correlated with higher infection rates in peritoneal macrophages of mice (Seabra et al. 2002) and also in chicken macrophages cell lines (Guillermo \& DaMatta 2004). In both systems, inducible NO synthase (iNOS) disappeared only in infected macrophages and only live parasites were capable of inhibiting NO production. This inhibition occurred after infection independently if macrophages were activated before of after infection (Seabra et al. 2002, Guillermo \& DaMatta 2004). The molecular mechanism behind this phenomenon was further investigated using the mice model. $T$. gondii infection induced a TGF-beta response, which lead to the disappearance of iNOS, explaining the inhibition of NO production (Seabra et al. 2004b). The secretion of TGF-beta was related to exposure of phosphatidylserine by tachyzoites (Seabra et al. 2004b). It was also shown that NFKB get out of the nucleus of activated macrophages and actin was depolymerized upon infection (Seabra et al. 2004b). However, the lack of lysosome fusion to the parasitophorous vacuoles was not related to the TGF-beta response, indicating that the evasion mechanism of $T$. gondii is multi-faceted. Unexpectedly, infection of activated macrophages by $T$. gondii did not increase the synthesis of polyamines as seen by monitoring ornithine descarboxilase activity after infection (Seabra et al. 2004a). Further studies are being carried out to determine if strains with different virulence inhibit NO the same way and the same way and the involvement of phosphatidylserine exposure in this evasion mechanism.

The Brazilian contribution is and has been important to $T$. gondii biology. The many recent descriptions and genotyping of new isolates of this parasite in Brazil, specially in chickens (Dubey et al. 2008) shows that lot of work need to be done to better understand virulence to different worm blood animals and humans and how the parasite has disperse around the world. Thus, we are sure that in the next 100 years the Brazilian contribution to the biology of this important intracellular pathogen will still be relevant.

\section{REFERENCES}

Andrade EF, Stumbo AC, Monteiro-Leal LH, Carvalho L, Barbosa HS 2001. Do microtubules around the Toxoplasma gondii-containing parasitophorous vacuole in skeletal muscle cells form a barrier for the phagolysosomal fusion? J Submicrosc Cytol Pathol 33: 337-341.

Arantes 1914. Contribuição ao estudo do Toxoplasma. Thesis, Faculdade Nacional de Medicina, Rio de Janeiro.

Barbosa HS, Ferreira-Silva MF, Guimarães EV, Carvalho L, Rodrigues RM 2005. Absence of vacuolar membrane involving Toxoplasma gondii during its intranuclear localization. J Parasitol 91: 182-184.

Baum J, Papenfuss AT, Baum B, Speed TP, Cowman AF 2006. Regulation of apicomplexan actin-based motility. Nat Rev Microbiol 4: 621-628.

Chagas C 1909. Nova tripanosomíase humana. Mem Inst Oswaldo Cruz 1: 159-218.
Cintra WM, De Souza W 1985. Distribution of intramembranous particles and filipin-sterol complexes in the cell membranes of Toxoplasma gondii. Eur J Cell Biol 37: 63-69.

DaMatta RA, Seabra SH, Manhaes DSL, De Souza W 2000. Nitric oxide is not involved in the killing of Trypanosoma cruzi by chicken macrophages. Parasitol Res 86: 239-243.

De Carvalho L, De Souza W 1989. Cytochemical localization of plasma membrane enzyme markers during interiorization of tachyzoites of Toxoplasma gondii by macrophages. J Protozool 36: 164-170.

De Carvalho L, De Souza W 1990. Internalization of surface anionic sites and phagosome-lysosome fusion during interaction of Toxoplasma gondii with macrophages. Eur J Cell Biol 51: 211-219.

De Carvalho L, Souto-Padrón T, De Souza W 1991. Localization of lectin-binding sites and sugar-binding proteins in tachyzoites of Toxoplasma gondii. J Parasitol 77: 156-161.

De Melo EJ, De Carvalho TU, De Souza W 1992. Penetration of Toxoplasma gondii into host cells induces changes in the distribution of the mitochondria and the endoplasmic reticulum. Cell Struct Funct 17: 311-317.

De Souza W 1972. Mise en evidence et structure d'un système microtubular in Toxoplasma gondii. C R Acad Sci (Paris) 275: 2899-2901.

De Souza W 1974a. The fine structure of the conoid of Toxoplasma gondii. Rev Inst Med Trop Sao Paulo 16: 32-38.

De Souza W 1974b. Aspectos ultra-estruturais do processo de divisão do Toxoplasma gondii. Rev Soc Bras Med Trop 8: 45-65.

De Souza W, Souto-Padrón T 1978. Ultrastructural localization of basic proteins on the conoid, rhoptries and micronemes of Toxoplasma gondii. Z Parasitenkd 56: 123-129.

Dubey JP, Velmurugan GV, Chockalingam A, Pena HF, de Oliveira LN, Leifer CA, Gennari SM, Bahia Oliveira LM, Su C 2008. Genetic diversity of Toxoplasma gondii isolates from chickens from Brazil. Vet Parasitol 157: 299-305

Ferreira S, De Carvalho TM, De Souza W 2003. Protein phosphorylation during the process of interaction of Toxoplasma gondii with host cells. J Submicrosc Cytol Pathol 35: 245-252.

Guillermo LVC, DaMatta RA 2004. Nitric oxide inhibition after Toxoplasma gondii infection of chicken macrophage cell lines. Poult Sci 83: 776-782.

Guimarães EV, De Carvalho L, Barbosa HS 2008. Primary culture of skeletal muscle cells as a model for studies of Toxoplasma gondii cystogenesis. J Parasitol 94: 72-83.

Guimarães FN, Meyer H 1942. Cultivo de "Toxoplasma" Nicolle \& Manceaux, 1909, em cultura de tecidos. Rev Bras Biol 2: 123-129.

Laveran A 1881. The pathology of malaria. Lancet 2: 840-841.

Laveran A 1903. Sur un protozoaire nouveau (Piroplasma donovani, Laveran et Mesnil), parasite d'une fièvre de l'Inde'. C R Acad Sci 137: 957-962.

MacLaren A, Attias M, De Souza W 2004. Aspects of the early moments of interaction between tachyzoites of Toxoplasma gondii with neutrophils. Vet Parasitol 125: 301-312.

Magno RC, Straker LC, De Souza W, Attias M 2005. Interrelations between the parasitophorous vacuole of Toxoplasma gondii and host cell organelles. Microsc Microanal 11: 166-174.

Meirelles MN, Martinez-Palomo A, Souto-Padron T, De Souza W 1983. Participation of concanavalin A binding sites in the interaction between Trypanosoma cruzi and macrophages. J Cell Sci 62: 287-299.

Meirelles MNL, De Souza W 1985. Killing of Trypanosoma cruzi and Leishmania mexicana, and survival of Toxoplasma gondii, in chicken macrophages in vitro. J Submicrosc Cytol Pathol 17: 327-334. 
Melo EJ, Attias M, De Souza W 2000. The single mitochondrion of tachyzoites of Toxoplasma gondii. J Struct Biol 130: 27-33.

Melo EJ, de Carvalho TU, de Souza W 1992. Penetration of Toxoplasma gondii into host cells induces changes in the distribution of the mitochondria and the endoplasmic reticulum. Cell Struct Funct 17: 311-317.

Meyer H, Andrade Mendonça I 1955. Electron microscopy observations of Toxoplasma Nicolle et Manceaux grown in tissue cultures (first note). Parasitology 45: 449-451.

Meyer H, Andrade Mendonça I 1957. Electron microscopic observations of Toxoplasma Nicolle et Manceaux in thin sections of tissue cultures (first note). Parasitology 47: 66-69.

Monteiro VG, de Melo EJ, Attias M, de Souza W 2001. Morphological changes during conoid extrusion in Toxoplasma gondii tachyzoites treated with calcium ionophore. J Struct Biol 136: 181-189.

Murray HW, Cohn ZA 1979. Macrophage oxygen-dependent antimicrobial activity. I. Susceptibility of Toxoplasma gondii to oxygen intermediates. $J$ Exp Med 150: 938-949.

Nicolle C, Manceaux L 1908. Sur une infection a corps de Leishman (ou organisms voisins) du gondi. C R Acad Sci 147: 763.

Pacheco-Soares C, De Souza W 2000. Labeled probes inserted in the macrophage membrane are transferred to the parasite surface and internalized during cell invasion by Toxoplasma gondii. Parasitol Res 86: 11-17.

Seabra SH, DaMatta RA, De Mello FG, de Souza W 2004. Endogenous polyamine levels in macrophage is sufficient to support growth of Toxoplasma gondii. J Parasitol 90: 455-460.
Seabra SH, de Souza W, DaMatta RA 2002. Toxoplasma gondii partially inhibits nitric oxide production of activated murine macrophages. Exp Parasitol 100: 62-70.

Seabra SH, de Souza W, DaMatta RA 2004. Toxoplasma gondii exposes phosphatidylserine that induces a TGF- $\beta$ autocrine effect orchestrating macrophages evasion. Biochem Biophys Res Commun 324: 744-752.

Silva SR, Meirelles SS, De Souza W 1982. Mechanism of entry of Toxoplasma gondii into vertebrate cells. J Submicrosc Cytol 14: 471-482.

Splendore A 1908. Um nuovo protozoa parassita dei conigli incontrato nelle lesioni anatomiche duna malattia che ricorda in molti ponti il kala-azar delluomo. Rev Soc Sci Sao Paulo 3: 109-112.

Splendore A 1909. Sopra um nuovo protozoo parasita dei conigli. Rev Soc Sci S Paulo 4: 75-79.

Stumbo AC, Barbosa HS, Carvalho TM, Porto LC, Carvalho L 2002. Anionic sites, fucose residues and class I human leukocyte antigen fate during interaction of Toxoplasma gondii with endothelial cells. Mem Inst Oswaldo Cruz 97: 517-522.

Torres CM 1927. Sur uns nouvelle maladie de l'homme, caracterisée par la presence dún parasite intracellulaire, très proche du Toxoplasme et de léncephalitozoon dans le tissu musculaire cardiaque, les muscles du squelette, le tissu sous-cutané et le tissu nerveux. C R Soc Biol 97: 1778-1779.

Viana G 1911. Contribuição para o estudo da anatomia patológica da Molestia de Carlos Chagas. Mem Inst Oswaldo Cruz 3: 276-292. 